\title{
Functional Selectivity and Classical Concepts of Quantitative Pharmacology
}

Jonathan D. Urban, William P. Clarke, Mark von Zastrow, David E. Nichols, Brian Kobilka, Harel Weinstein, Jonathan A. Javitch, Bryan L. Roth, Arthur Christopoulos Patrick M. Sexton, Keith J. Miller, Michael Spedding, and Richard B. Mailman

Curriculum in Toxicology (J.D.U., R.B.M.) and Departments of Pharmacology, Psychiatry Medicinal Chemistry (B.L.R., R.B.M.), and Neurology (R.B.M.), University of North Carolina, Chapel Hill, North Carolina; Department of Pharmacology, University of Texas Health Science Center, San Antonio, Texas (W.P.C.); Departments of Psychiatry and Cellular and Molecular Pharmacology, University of California, San Francisco, California (M.v.Z); Department of Medicinal Chemistry and Molecular Pharmacology, School of Pharmacy and Pharmaceutical Sciences, Purdue University, West Lafayette, Indiana (D.E.N.); Department of Molecular and Cellular Physiology, Stanford University, Palo Alto, California (B.K.); Department of Physiology and Biophysics, and Institute for Computational Biomedicine, Weill Medical College of Cornell University, New York, New York (H.W.); Center for Molecular Recognition, and Departments of Psychiatry and Pharmacology, Columbia University College of Physicians and Surgeons, New York, New York (J.A.J.); Department of Pharmacology, Monash University, Clayton, Victoria, Australia (A.C., P.M.S.); Obesity Department, Pharmaceutical Research Institute, Bristol-Myers Squibb, Princeton, New Jersey (K.J.M.); and Institute de Recherches Servier, Suresnes, France (M.S.)

Received April 11, 2006; accepted June 23, 2006

\section{ABSTRACT}

The concept of intrinsic efficacy has been enshrined in pharmacology for half of a century, yet recent data have revealed that many ligands can differentially activate signaling pathways mediated via a single G protein-coupled receptor in a manner that challenges the traditional definition of intrinsic efficacy. Some terms for this phenomenon include functional selectivity, agonist-directed trafficking, and biased agonism. At the extreme, functionally selective ligands may be both agonists and antagonists at different functions mediated by the same receptor. Data illustrating this phenomenon are presented from serotonin, opioid, dopamine, vasopressin, and adrenergic receptor systems. A variety of mechanisms may influence this apparently ubiquitous phenomenon. It may be initiated by differences in ligand-induced intermediate conformational states, as shown for the $\beta_{2}$-adrenergic receptor. Subsequent mecha- nisms that may play a role include diversity of $\mathrm{G}$ proteins, scaffolding and signaling partners, and receptor oligomers. Clearly, expanded research is needed to elucidate the proximal (e.g., how functionally selective ligands cause conformational changes that initiate differential signaling), intermediate (mechanisms that translate conformation changes into differential signaling), and distal mechanisms (differential effects on target tissue or organism). Besides the heuristically interesting nature of functional selectivity, there is a clear impact on drug discovery, because this mechanism raises the possibility of selecting or designing novel ligands that differentially activate only a subset of functions of a single receptor, thereby optimizing therapeutic action. It also may be timely to revise classic concepts in quantitative pharmacology and relevant pharmacological conventions to incorporate these new concepts.
Conflicts of interest: Dr Michael Spedding is both chairman for NC-IUPHAR and deputy director of research for Servier. Dr. Keith Miller is an employee of Bristol-Myers Squibb, Inc. Drs. Mailman and Nichols, the University of North Carolina, and Purdue University have a financial interest in BioValve Technologies, the licensee of compounds mentioned in this article. The opinions presented herein are those of the authors, and not those of any other party.

Article, publication date, and citation information can be found at http://jpet.aspetjournals.org.

doi:10.1124/jpet.106.104463.

\section{Receptor Pharmacology for the New Millennium}

For the last half-century, pharmacological theory has posited that ligands could be characterized by the nature of the functional effects elicited by their interaction with their tar- 
get receptor. These effects are governed by two important properties: 1) affinity, the property of attraction between a ligand and its receptor, and 2) efficacy, the property that allows ligands, once bound, to produce a response (Kenakin, 1997). This concept has led to the classification of receptor ligands as full agonists, partial agonists, neutral antagonists, or inverse agonists. Perhaps the key idea that governs this classification is the notion of "intrinsic efficacy", originally proposed by Furchgott (1966) as a measure of the stimulus per receptor molecule produced by a ligand. According to this notion, full agonists possess sufficiently high intrinsic efficacy, such that they maximally stimulate all cellular responses linked to a given receptor. Partial agonists possess lower degrees of intrinsic efficacy (leading to submaximal responses), whereas inverse agonists reduce constitutive (ligand-independent, basal) receptor signaling. Neutral antagonists possess no intrinsic efficacy but occupy the receptor to block the effects of full, partial, or inverse agonists. This idea has also led to the assumption, dearly held in pharmacology, that the ability of the ligand to impart (or reduce) stimulus once that ligand is bound to the receptor is an inherent property of the ligand-receptor complex. Intrinsic efficacy is thus differentiated from the more operational term "intrinsic activity" (Ariens, 1954) that simply refers to the maximal effect $\left(E_{\max }\right)$ of a ligand relative to a reference agonist in a given experimental system.

Therefore, in classical pharmacological terms, intrinsic efficacy has been viewed as a system-independent parameter that is constant for each ligand at a given receptor, irrespective of where that receptor is expressed. Any differences in the expression of agonism by a ligand between cell and tissue types were assumed simply to reflect differences in receptor density and/or the strength of stimulus-response coupling. In other words, the classification of compounds on the basis of intrinsic efficacy only allowed for variations in the quantity of the stimulus that was imparted to the cell, but not the quality. A full agonist would be expected to activate all of the signaling pathways linked to a receptor to the same degree as the endogenous ligand for that receptor. In contrast, a ligand that antagonizes one signaling pathway via a specific receptor should antagonize every pathway coupled to that receptor to the same extent. One consequence of this theory was the weight it added to Ehrlich's idea of a therapeutic "magic bullet". It led to a focus on discovery of new receptor ligands with high affinity and having specific functional characteristics at a single target. Although modern drug discovery recently has recognized that there is value in ligands that act by simultaneously targeting multiple receptors (Roth et al., 2004), there is still the widespread view that the characteristics of ligands at target receptors can be described by their "intrinsic efficacy". In fact, the notion that intrinsic efficacy is system-independent forms a major underlying premise in drug discovery today - that the pharmacological characteristics of a drug tested in an experimental model system can be extrapolated to all systems. As discussed below, this premise is frequently incorrect.

This change in perspective has been spurred by data emerging within the past decade in which certain ligands were shown to have quite diverse functional consequences mediated via a single receptor. Because these data were clearly not consistent with classical pharmacological concepts, they were often dismissed as artifacts caused by dif- ferences in "strength of signaling", receptor reserve, undetected interactions with unknown receptors, effects of trace contaminants or drug metabolites, and/or similar mechanisms. Yet as more and more data have been amassed with a variety of different receptors, it is becoming clear that the classical concept of "intrinsic efficacy" as a system-independent constant, although once having conceptual utility, is probably not correct. Indeed, almost every researcher reaching this conclusion felt it important enough to coin their own descriptive terms that now include "functional selectivity", "agonist-directed trafficking of receptor stimulus", "biased agonism", "protean agonism", "differential engagement", and "stimulus trafficking" (to name just a few).

It was the concatenation of this research that led to two symposia at the Experimental Biology 2005 meeting whose essence is captured in this Perspective. We propose that ligands induce unique, ligand-specific receptor conformations that frequently can result in differential activation of signal transduction pathways associated with that particular receptor (Roth and Chuang, 1987; Kenakin, 1995; Mailman et al., 1997, 1998; Clarke and Bond, 1998; Ghanouni et al., 2001; Gonzalez-Maeso et al., 2003). This differential activation may be expressed as differences in intrinsic activity and/or potency at one signaling pathway versus another that are not due to differences in affinity at the mediating receptor. Throughout this article, this concept is termed "functional selectivity", yet it must be made clear that this is not a IUPHAR-accepted convention. We chose it for the symposium titles, because it is a purely operational term that can accommodate one or any combination of several involved mechanisms (vide infra). Indeed, as is noted below, the participants suggested that it may be timely to settle on conventions that will help to focus the relevant literature in this area. Although most of the research that was presented is recent and uses a variety of modern techniques, we are aware that ideas related to "functional mismatches" had been theorized earlier, sometimes going back decades (Portoghese, 1965; Jim et al., 1985; Roth and Chuang, 1987). We summarize below some of the data from our laboratories that support this concept, but we recognize that others also have made similar observations and come to similar conclusions.

\section{Examples of Functional Selectivity}

\section{Atypical Agonists of $5-\mathrm{HT}_{2}$ Serotonin Receptors}

There have been a plethora of observations of functional selectivity made by a number of groups investigating serotonin receptor systems. The effector that has been best characterized with respect to $5-\mathrm{HT}_{2}$ signaling involves the $\mathrm{G} \alpha_{\mathrm{q}}$ stimulation of phospholipase $\mathrm{C}$ (PLC), leading to the formation of inositol phosphates (IP) and diacylglycerol, thereby modulating intracellular calcium $\left[\mathrm{Ca}^{2+}\right]_{\mathrm{i}}$ (Hoyer et al., 1994). This receptor family also has been shown to mediate the release of arachidonic acid (AA), presumably through the activation of phospholipase $\mathrm{A}_{2}\left(\mathrm{PLA}_{2}\right)$ (Felder et al., 1990), an enzyme that acts on membrane phospholipids.

Berg et al. (1998b) reported the capability of certain serotonergic ligands to differentially activate these signal transduction pathways associated with the human serotonin $5-\mathrm{HT}_{2 \mathrm{~A}}$ and $5-\mathrm{HT}_{2 \mathrm{C}}$ receptors. They observed that the relative efficacy of a series of ligands for each of the receptors differed depending upon whether PLC-mediated accumula- 
tion of IP or $\mathrm{PLA}_{2}$-mediated release of AA was measured (Fig. 1). Important aspects of the experimental design were that responses to the reference drug were obtained along with each test ligand in every experiment, and both signal transduction responses were measured simultaneously from the same cells, thereby obviating methodological reasons for response-dependent differences in relative agonist efficacy (Berg et al., 1998a). The significance of these differences in relative efficacy was further supported by the lack of difference in relative agonist efficacy between the PLC-IP response and increase in $\left[\mathrm{Ca}^{2+}\right]_{\mathrm{i}}$ levels of which agonists would not be expected to regulate differentially.

Further studies of the $5-\mathrm{HT}_{2 \mathrm{C}}$ receptor demonstrate that the ability of agonists to activate receptor desensitization mechanisms also seems to be ligand-dependent (Fig. 1). Marked differences are observed in the relative efficacy of agonists to rapidly desensitize the $5-\mathrm{HT}_{2 \mathrm{C}}$-mediated PLC-IP and $\mathrm{PLA}_{2}-\mathrm{AA}$ response pathways, but these efficacies of desensitization did not correspond to the relative efficacies of pathway activation (Stout et al., 2002). Examination of the $5-\mathrm{HT}_{2 \mathrm{C}}$ receptor molecular structure indicates that the second intracellular loop plays a crucial role in transmitting agonist-specific information to the PLC-IP and $\mathrm{PLA}_{2}-\mathrm{AA}$ signal response pathways. It was observed that, by changing three amino acids within this region (positions 156, 158, and 160 from Ile-Asn-Ile to either Val-Ser-Val or Val-Glu-Val), the capacity of $5-\mathrm{HT}_{2 \mathrm{C}}$ agonists to differentially signal through these response pathways was compromised (Berg et al., 2001). This example, a result of mRNA editing, highlights the importance of how subtle changes in receptor structure and its effect on conformation (Visiers et al., 2001) can ultimately affect the cellular signaling responses.

The concept of functional selectivity also applies to compounds that are classified as inverse agonists, some of which may have different functional characteristics at other signaling pathways mediated by the targeted receptor. An example of this is SB 242084 (Cussac et al., 2002), a functionally selective ligand that is a strong inverse agonist for $5-\mathrm{HT}_{2 \mathrm{C}}$

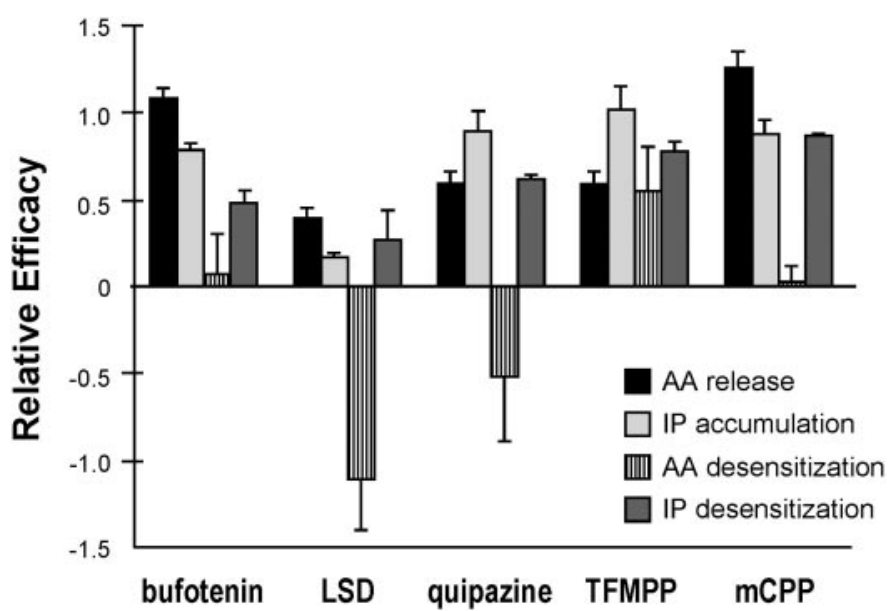

Fig. 1. Functional selectivity at the $5-\mathrm{HT}_{2 \mathrm{C}}$ receptor. Bars represent the ratio of the maximal effect of the test ligands to that of the reference ligand, 5-HT. Note, for example, that bufotenin is a full agonist at AA release and a partial agonist at IP accumulation, whereas $m$-trifluoromethylphenylpiperazine (TFMPP) is a full agonist at IP accumulation but has only partial intrinsic activity at AA release. Other examples violating the classically held tenet of intrinsic efficacy (i.e., response independence) are also seen in the data from Stout et al. (2002). receptor-mediated $\mathrm{PLA}_{2}-\mathrm{AA}$ release and $\mathrm{G} \alpha_{\mathrm{i}}$ but an agonist for PLC-IP (De Deurwaerdere et al., 2004). These observations further support the notion of ligand-induced differential signaling and highlight the importance of referencing response and the conditions of that response when describing the intrinsic activity of a ligand.

Other interesting data have arisen from studies that looked specifically at hallucinogens and their differential signaling through the $5-\mathrm{HT}_{2 \mathrm{~A}}$ receptor. Although the PLC-IP effector is an easy pathway to evaluate experimentally, there had been no proof that the hallucinogenic effects of compounds, such as LSD, rely on its activation. A recent report (Rabin et al., 2002) emphasized that there is no correlation between hallucinogenic activity and activation of the PLC effector pathway. Kurrasch-Orbaugh et al. (2003b) compared the effects of LSD and DOB (a hallucinogenic phenethylamine derivative) on $5-\mathrm{HT}_{2 \mathrm{~A}}$ receptor-mediated accumulation of $\mathrm{IP}_{3}$ and found that both had significant potency for this pathway $\left(\mathrm{EC}_{50}=10\right.$ and $70 \mathrm{nM}$, respectively), yet LSD demonstrated little intrinsic activity $(22 \%)$ relative to that $(80 \%)$ of DOB.

The discrepancies between PLC activation and in vivo pharmacology led to the investigation of other effector pathways associated with $5-\mathrm{HT}_{2 \mathrm{~A}}$ receptor activation. As mentioned previously, $5-\mathrm{HT}_{2 \mathrm{~A}}$ receptor stimulation also leads to the release of $\mathrm{AA}$. A series of $5-\mathrm{HT}_{2 \mathrm{~A}}$ agonists was found to have varying potencies and intrinsic activities for the accumulation of $\mathrm{IP}_{3}$ or AA (Fig. 2), but it appeared that activation of the latter pathway was more likely to be associated with hallucinogenic effects than $\mathrm{IP}_{3}$ accumulation (Kurrasch-Orbaugh et al., 2003a). Further investigation of hallucinogenmediated release of AA demonstrated that this functional pathway is more complex than originally thought. In vitro, after a 30-min agonist stimulation, it has been shown that AA signaling probably involves $\mathrm{G} \alpha_{\mathrm{i} / \mathrm{o}}$ and $\mathrm{G} \alpha_{12 / 13}$, as well as $\mathrm{G} \beta \gamma$, Rho, mitogen-activated protein kinase kinase $1 / 2$, and p38 MAPK (Kurrasch-Orbaugh et al., 2003a), indicating that more than one signaling cascade is responsible for $5-\mathrm{HT}_{2 \mathrm{~A}}$ receptor-mediated AA release. More recent studies have demonstrated that $5-\mathrm{HT}_{2 \mathrm{~A}}$ receptor activation also leads to the formation of the 2-arachidonylglycerol, an endocannabinoid whose formation is partially dependent on the PLCmediated accumulation of $\mathrm{IP}_{3}$ (Parrish and Nichols, 2006).

Therefore, it seems that activation of the $5-\mathrm{HT}_{2 \mathrm{~A}}$ receptor leads to the production of at least three distinct biochemical signals ( $\mathrm{IP}_{3} /$ diacylglycerol, $\mathrm{AA}$, and 2-arachidonylglycerol) and that the relative activation of these pathways varies with the ligand under investigation. Moreover, the "transcriptome fingerprints" of various agonists activating only the $5-\mathrm{HT}_{2 \mathrm{~A}}$ receptors were shown to differ (Gonzalez-Maeso et al., 2003). However, at present, there is no clear evidence to suggest what structural characteristics of a ligand promote the activation of one effector over the others. The induction of unique receptor conformations by each ligand would, in theory, promote distinct affinities and coupling efficiencies to the various G proteins endogenously expressed in cell models and also possibly to other proteins that interact with the receptors in modulating signal transduction. Virtual docking of enantiomeric phenethylamines into a homology model of the $5-\mathrm{HT}_{2 \mathrm{~A}}$ receptor has been employed to investigate the possibility that subtle structural differences among ligands might be responsible for distinct receptor conformations and hence 

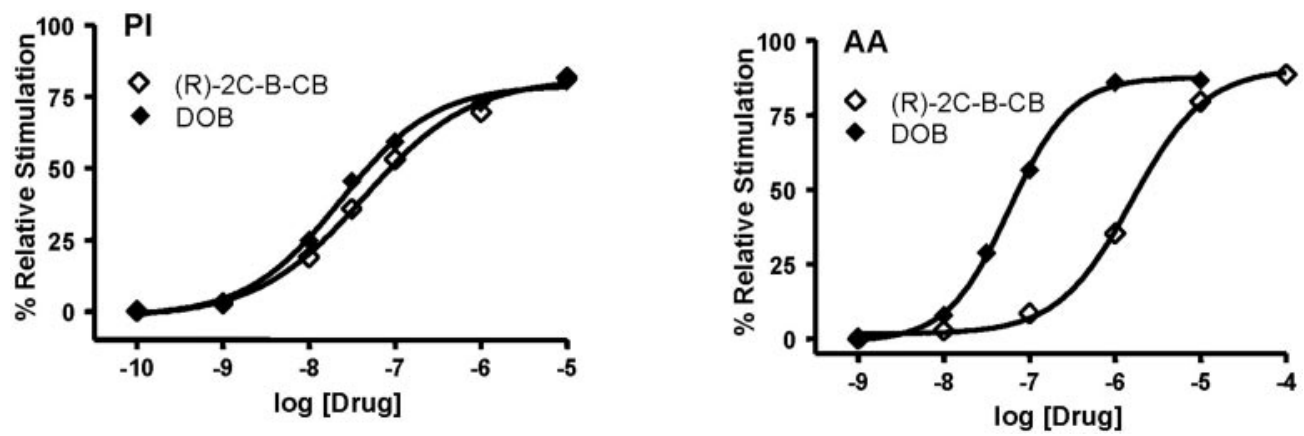

Fig. 2. Functional selectivity at $5-\mathrm{HT}_{2 \mathrm{~A}}$ receptors. The panel on the left illustrates relative potency of two agonist ligands in stimulating PLC, measured by the accumulation of inositol phosphates in a stable rat 5-HT ${ }_{2 \mathrm{~A}} \mathrm{NIH}-3 \mathrm{~T} 3$ cell line. The $\mathrm{EC}_{50}$ values for DOB and $(R)-2 \mathrm{C}-\mathrm{B}-\mathrm{CB}$ are 23 and $43 \mathrm{nM}$, respectively, only 2 -fold different, with similar intrinsic activities. By contrast, the panel on the right shows the potency of the same two ligands in stimulating AA release from these cells, $\mathrm{EC}_{50}$ values of $58 \mathrm{nM}$ and $1.6 \mu \mathrm{M}$, respectively, their potencies differing in this signaling pathway by nearly 30 -fold. Although DOB is clearly not functionally selective, $(R)-2 \mathrm{C}-\mathrm{B}-\mathrm{CB}$, a structurally related ligand, is 36 -fold selective in stimulating the PLC signaling pathway over AA production.

the unique pharmacologies associated with a number of the $5-\mathrm{HT}_{2 \mathrm{~A}}$ ligands (Parrish et al., 2005). These studies indicate that there is much more research to be done before the molecular determinants of functional selectivity in any GPCR paradigm are to be elucidated (Parrish et al., 2005).

\section{5- $\mathrm{HT}_{2}$ Serotonin Receptor "Antagonists" and Collateral Efficacy}

Most of the examples of compounds that seem to activate 5-HT receptors differentially are ligands that were originally thought to be typical agonists, yet there are examples in which presumed antagonists actually demonstrate an agonist-like activity. For example, chronic antagonist treatment often leads to compensatory receptor up-regulation (Hess et al., 1988) that may be one of the mechanisms involved in the resultant "supersensitivity" of receptor signaling (Schulz et al., 1979). In spite of this fact, it has long been known that chronic antagonist administration leads to apparent receptor down-regulation and desensitization of signaling with some GPCRs (for recent reviews, see Kenakin, 2005; O'Connor and Roth, 2005). This paradoxical regulation of GPCRs by antagonists was discovered and has been most convincingly demonstrated for $5-\mathrm{HT}_{2}$ family serotonin receptors.

Peroutka and Snyder (1980) were the first to demonstrate that chronic treatment with $5-\mathrm{HT}_{2 \mathrm{~A}}$ antagonists leads to apparent $5-\mathrm{HT}_{2 \mathrm{~A}}$ receptor down-regulation in vivo-a finding that has now been replicated in over 100 published studies (see Gray and Roth, 2001 for review), of which many have shed additional light on this phenomenon. It has been demonstrated that: 1) antagonists induce $5-\mathrm{HT}_{2 \mathrm{~A}}$ receptor internalization and down-regulation in vitro when cloned receptors are expressed in heterologous expression systems (Berry et al., 1996; Newton and Elliott, 1997; Willins et al., 1999; Bhatnagar et al., 2001); 2) antagonists induce $5-\mathrm{HT}_{2 \mathrm{~A}}$ receptor internalization in vivo in individual cortical neurons (Willins et al., 1999); 3) antagonist-induced desensitization requires internalization (Hanley and Hensler, 2002); and 4) antagonist-induced receptor down-regulation does not occur due to changes in receptor synthesis (Roth and Ciaranello, 1991; Anji et al., 2000). Antagonist-induced internalization, an example of "collateral efficacy" (Kenakin, 2005), also has been demonstrated with cholecystokinin and other peptide receptors (Roettger et al., 1997; Sneddon et al., 2003).

These observations suggest that the antagonist-induced internalization of $5-\mathrm{HT}_{2 \mathrm{~A}}$ and other GPCRs may have therapeutic potential. For example, Elphick et al. (2004) recently demonstrated that the JC Virus-the causative agent of progressive multifocal leukoencephalopathy-uses $5-\mathrm{HT}_{2 \mathrm{~A}}$ receptors to infect cells and that some $5-\mathrm{HT}_{2 \mathrm{~A}}$ antagonists known to induce receptor internalization can block this viral infection. Further study has shown that antagonists that induce $5-\mathrm{HT}_{2 \mathrm{~A}}$ receptor internalization in vitro (e.g., mirtazepine) are able to block viral infection, whereas those that do not (e.g., cyproheptadine) are less protective (W. Attwood, personal communication) (O'Connor and Roth, 2005). Therefore, it stands to reason that prophylactic treatment with $5-\mathrm{HT}_{2 \mathrm{~A}}$ antagonists with collateral efficacy is likely to be therapeutic, whereas treatment with antagonists that fail to internalize the 5- $\mathrm{HT}_{2 \mathrm{~A}}$ receptor is not (O'Connor and Roth, $2005)$. Indeed, antagonists with the ability to induce $5-\mathrm{HT}_{2 \mathrm{~A}}$ receptor down-regulation might be therapeutically useful, for example, for individuals at risk for progressive multifocal leukoencephalopathy as a side effect of treatment with drugs like natalizumab (Engelhardt and Briskin, 2005; Ransohoff, 2005; Van et al., 2005).

\section{Functional Selectivity at $\mu$-Opioid, $\boldsymbol{\beta}_{2}$-Adrenergic, and V2 Vasopressin Receptors}

Serotonergic receptors are not the only family of receptors with which the phenomenon of functional selectivity has been observed. There is both pharmacological and biochemical evidence for the agonist-selective regulation of $\mu$-opioid and $\beta_{2}$-adrenergic receptor( $\mathrm{s}$ ( $\left.\beta_{2} \mathrm{AR}\right)$. Some of these observations were made in studies designed to determine the ability of ligands to produce an endocytic effect on the receptor under investigation, thereby affecting receptor regulation. Using epifluorescence microscopy of epitope-labeled $\mu$-opioid receptor, it was possible to visualize differences in $\mu$-opioid receptor agonist induction of receptor endocytosis in transfected fibroblasts (Keith et al., 1996) and in neurons expressing endogenous receptors in vivo (Sternini et al., 1996; Keith et al., 1998). Furthermore, by comparing the "endocytic efficacies" of these compounds with their intrinsic activities for other effectors coupled to $\mu$-opioid receptor (e.g., adenylate cyclase activity and GIRK channel regulation), they were able to illustrate functional differences among agonists that were not predicted by the two-state receptor model. For example, the opioid peptide DAMGO induces significant recep- 
tor endocytosis similar to methadone, whereas morphine elicits a much more subtle endocytic response (Keith et al., 1996; Whistler et al., 1999). However, morphine is able to activate GIRK channels via $\mu$-opioid receptors in transfected fibroblasts with an intrinsic activity similar to or greater than that of methadone (Whistler et al., 1999), and similar effects have been reported in situ (Alvarez et al., 2002). These data suggest that an alternative receptor model is in order, one that takes into consideration at least two different active receptor conformations that can be specifically induced, or selected for, by a particular ligand.

Such observations have prompted further studies designed to elucidate the mechanism behind differential receptor endocytosis. Significant evidence had suggested that ligandspecific differential receptor phosphorylation of the $\mu$-opioid receptor was a potential mechanism by which downstream cellular effectors could distinguish the different functional effects elicited by ligands (Yu et al., 1997; Whistler and von Zastrow, 1998; Zhang et al., 1998; He et al., 2002). Moreover, a similar observation had been made by Benovic et al. (1988) in the $\beta_{2} \mathrm{AR}$ system in vitro. A recent study has examined whether the $\beta_{2} \mathrm{AR}$ has a single or multiple agonist-induced phosphorylated states in an intact cell. Trester-Zedlitz et al. (2005) incorporated a protein analytical approach that took advantage of recent improvements in mass spectrometry methods (specifically, matrix-assisted laser desorption ionization-time of flight) and protein enrichment procedures (e.g., stable isotope labeling with amino acids in culture and immobilized metal affinity chromatography) that allow for the biochemical analysis or "read-out" of ligand-induced posttranslational modifications to $\beta_{2} \mathrm{AR}$ isolated from a stable human embryonic kidney cell line. These studies indicate that there are not only multiple phosphorylation sites between the third intracellular loop and carboxyl-terminal cytoplasmic domain of the $\beta_{2} \mathrm{AR}$ but that there seems to be an agonist bias that determines the specific phosphorylation state (Trester-Zedlitz et al., 2005). Although mapping the specific amino acid residues that are phosphorylated in response to a specific ligand is still a work in progress, the general site locations are consistent with previous studies of ligand-induced desensitization and GRK activity (Hausdorff et al., 1991; Tran et al., 2004). These data lend support to the hypothesis of differential regulation of receptor endocytosis by distinct ligands via agonist-selective posttranslational modifications, such as phosphorylation.

More pertinent to the clinic are some preliminary data that suggest that there may be a genetic component to functional selectivity as it relates to specific physiological syndromes. A screening approach has identified C5a complement receptor mutations that separate ligand dependence of endocytosis from signaling (Baranski et al., 1999; Whistler et al., 2002). A more recent study reached a similar conclusion for the V2 vasopressin receptor (V2R) and suggested that this distinction is the basis of a newly defined human genetic disease. Several patients, presumptively diagnosed with the syndrome of inappropriate antidiuretic hormone secretion, were shown to express one of two gain-of-function point mutations of Arg137 (to Cys and Leu) of the V2R (Feldman et al., 2005). Arg137 is located in the conserved " $\mathrm{DR}(\mathrm{Y} / \mathrm{H})$ " motif of the receptor, and the mutations were shown to cause constitutive activation of receptor signaling, defining the "nephrogenic syndrome of inappropriate antidiuresis" or NSIAD. This study is particularly interesting because the alternate mutation of precisely the same residue to His causes reduced receptor signaling and the opposite disease state of nephrogenic diabetes insipidus (Rosenthal et al., 1993). Interestingly, the nephrogenic diabetes insipidus mutant V2R is weakly activated by agonist ligands because it is bound to arrestins and internalized in a constitutive (or ligand-independent) manner (Barak et al., 2001). Conversely, the mutant V2R producing NSIAD exhibits constitutive signaling, yet its internalization and arrestin association are strongly ligand-dependent (Vargas et al., submitted for publication). This mutational "reversal" in ligand dependence for signaling and internalization supports the hypothesis that there may exist multiple ligand-induced conformations of the V2R, differing in relative signaling and internalization activities, and that these may underlie essentially opposite human disease states.

\section{Functional Selectivity at $D_{2 L}$ and $D_{1}$ Dopamine Receptors}

Dopamine receptors represent another subset of GPCRs that have been observed to differentially activate associated signaling cascades in response to certain compounds. In fact, much of the work on functional selectivity through dopamine receptors was an unexpected result of efforts directed at the rational discovery of novel $\mathrm{D}_{1}$ dopamine ligands (Charifson et al., 1989; Mottola et al., 1996; Qandil et al., 2003). When dihydrexidine (DHX), the first high-affinity full agonist for the $\mathrm{D}_{1}$ dopamine receptor was characterized (Lovenberg et al., 1989), it was found to have only a 10 -fold selectivity for $\mathrm{D}_{1}$ versus $\mathrm{D}_{2}$ receptors (Brewster et al., 1990; Mottola et al., 1992). DHX and its congener $N$-propylDHX were initially characterized as full agonists at the $\mathrm{D}_{2}$ receptor, because they were as efficacious as dopamine in inhibiting cAMP synthesis and efflux in striatal slices, inhibiting prolactin release in vivo, and stimulating GTP $\gamma \mathrm{S}$ binding in rat substantia nigral tissue (Mottola et al., 1992; Kilts et al., 2002). However, further characterization of the functional profile of these compounds demonstrated that they are not typical full $\mathrm{D}_{2}$ receptor agonists. Neither DHX nor $N$-propylDHX is able to inhibit the synthesis and release of dopamine in rat striatum or inhibit the firing of nigral dopaminergic neurons (Fig. 3) (Kilts et al., 2002; Mottola et al., 2002). Effects in all of these functional assays would be expected for typical $\mathrm{D}_{2}$ receptor agonists. Thus, although DHX and $\mathrm{N}$-propylDHX bind to the $\mathrm{D}_{2}$ receptors present in both neural tracks, they cause differential activation of specific signaling pathways, an overall concept that led to the coining of the term "functional selectivity" (Lawler et al., 1994, 1999; Mailman et al., 1997, 1998). Interestingly, the functional selectivity of $N$ propylDHX in vitro may explain its unexpected behavioral effects in vivo (Smith et al., 1997).

Similar trends were observed in vitro (rat lactotrophs as well as MN9D and Chinese hamster ovary cells stably expressing the $\mathrm{D}_{2}$ receptor), verifying that the in situ observations are not artifacts produced by the activation of other GPCRs and further confirming that functional selectivity as observed for specific dopaminergic compounds is not an epiphenomenon associated with a particular signaling model (Kilts et al., 2002; Mottola et al., 2002; Gay et al., 2004). This functionally selective profile is not unique to DHX and $N$ propylDHX, as functional selectivity has been shown for other $\mathrm{D}_{2}$ receptor ligands (e.g., propylnorapomorphine and 
modeling indicates that the salbutamol aromatic ring does not interact with the same receptor residues as the catechol moiety of catecholamines, suggesting that salbutamol induces an active conformation distinct from those induced by catecholamines (Swaminath et al., 2005).

These results suggest that the disruption of all of the interactions that maintain the basal conformational state is not required for a ligand to produce some level of receptor activation. It is likely that structurally distinct ligands are able to break different combinations of the basal state-stabilizing interactions either directly by binding to amino acids that are involved in these intramolecular interactions or indirectly by stabilizing new intramolecular interactions. These ligand-specific conformational changes may be responsible for differential activation of the signaling cascades of a receptor (Swaminath et al., 2005). Furthermore, structurally distinct ligands are able to break different combinations of the basal state-stabilizing interactions to produce unique conformational states, which ultimately may be responsible for differential activation of the signaling cascades of a receptor (Swaminath et al., 2005).

\section{Computational and Theoretical Approaches to Understanding Functional Selectivity}

In addressing the apparent disruption of the traditional thought in pharmacology generated by the functional selectivity phenomenon, there has been a focus on the reasons that make the observations leading to the definition of "functional selectivity" appear uncommon to classical pharmacology. It has been suggested that, to incorporate such apparently discordant observations into the pharmacological characterization of drug action, it may be necessary to reevaluate the current axioms underlying the pharmacological definitions. This re-evaluation is provoked by experimental results from newly acquired abilities to 1 ) identify and test naturally occurring molecular variations of both receptors and ligands (e.g., peptide hormones), 2) engineer novel molecular structures (e.g., constitutively active constructs) that exhibit new types of pharmacological properties, 3) create uncommon adjacencies of receptors on the cell surface, allowing for new types of heterodimerizations, and 4) test a much larger variety (structurally and chemically) of artificially created ligands for the receptors. As a result of these developments, the phenomena that lead to the definition of "functional selectivity" must be examined to establish 1) whether the novel (or puzzling) phenotypes simply reveal underlying mechanisms that had not been challenged in classical pharmacology and 2) whether these mechanisms depend on the same underlying structure-function rules that explain classical pharmacology but are richer in phenotypes.

In the context of the latter point, it has been suggested that the approaches must address structure-based mechanisms for modes of receptor activation, including a mechanistic understanding of the molecular processes involved in the discrimination between agonists and antagonists, full versus partial agonists, neutral antagonists versus inverse agonists, and the molecular details of constitutive activity to various degrees (Ebersole et al., 2003). Moreover, the protein-protein interactions responsible for homo- and hetero-oligomerization (Filizola and Weinstein, 2005), as well as for the integration of the receptors in the signaling pathways in the cell (Weinstein, 2006), are likely to play an important role in determining the properties underlying the observed departures from what is considered to be "classical pharmacological activity".

Point B can be illustrated by examining results from combined experimental and computational approaches applied to investigating mechanisms essential to the hallucinogenic drug action of several classes of $5-\mathrm{HT}_{2}$ receptor compounds. The goal of this endeavor is to uncover the subtle consequences of ligand-receptor interactions as they are mechanistically related to the subcellular elements ultimately responsible for hallucinogenic action (reviewed in Weinstein, 2006). It provides an excellent example of apparent pharmacological conundrums related to functional selectivity of the $5-\mathrm{HT}_{2 \mathrm{~A}}$ receptor demonstrated by the elegant definition of the "transcriptome fingerprint" (Gonzalez-Maeso et al., 2003).

In seeking the structural context of the ligand-determined receptor mechanisms, this interdisciplinary research has illuminated a number of conserved structural motifs in the configurations of rhodopsin-like GPCRs that are implicated in receptor signaling by acting as functional microdomains (Weinstein, 2006). Examples include 1) the NPxxY motif of TM7 (Prioleau et al., 2002) and 2) the cluster of aromatic residues in TM6 that straddles a universally conserved proline and is thought to act as a "toggle switch", thereby conveying the consequences of the ligand-binding event to the rearrangements associated with receptor activation (as reviewed in Visiers et al., 2002).

Given this defined set of sites involved in ligand-dependent transitions in the conformation of the GPCRs, these studies have shown that structurally similar ligands can produce different ligand-dependent modes of receptor activation by aligning themselves in different positions within the receptor-binding pocket. For example, it seems that bulky substitutions of the cationic moiety in the hallucinogenic compounds allow these ligands to adopt unique positions within the $5-\mathrm{HT}_{2 \mathrm{~A}}$ receptor-binding pocket relative to their nonhallucinogenic congeners (Ebersole et al., 2003). These observations highlight the idea that liganddependent conformations are able to produce functionally selective responses at the cellular level that ultimately can be translated to a unique physiological effect. This mechanistic translation depends on the interactions of the receptor molecule with its environment, such as those in oligomer formation (see below).

The oligomerization mechanism is only one form of integration of the GPCR into the signaling networks of the cell, as different receptor conformations produced by ligand binding could select for interaction different proteins (e.g., PDZ domains, kinases) from the downstream signaling pathway (Fig. 4). Consequently, it is important to integrate the examination of the putative mechanisms leading to the functional selectivity paradigm with the subcellular, cellular, and physiological levels of GPCR signaling. A powerful tool for this integrative approach is quantitative modeling of signaling pathways as mathematical representations that are amenable to computational simulations (Campagne et al., 2004). To produce useful models of these signaling systems, the components must be represented with the highest level of physical realism possible at our current understanding of cell physiology. 


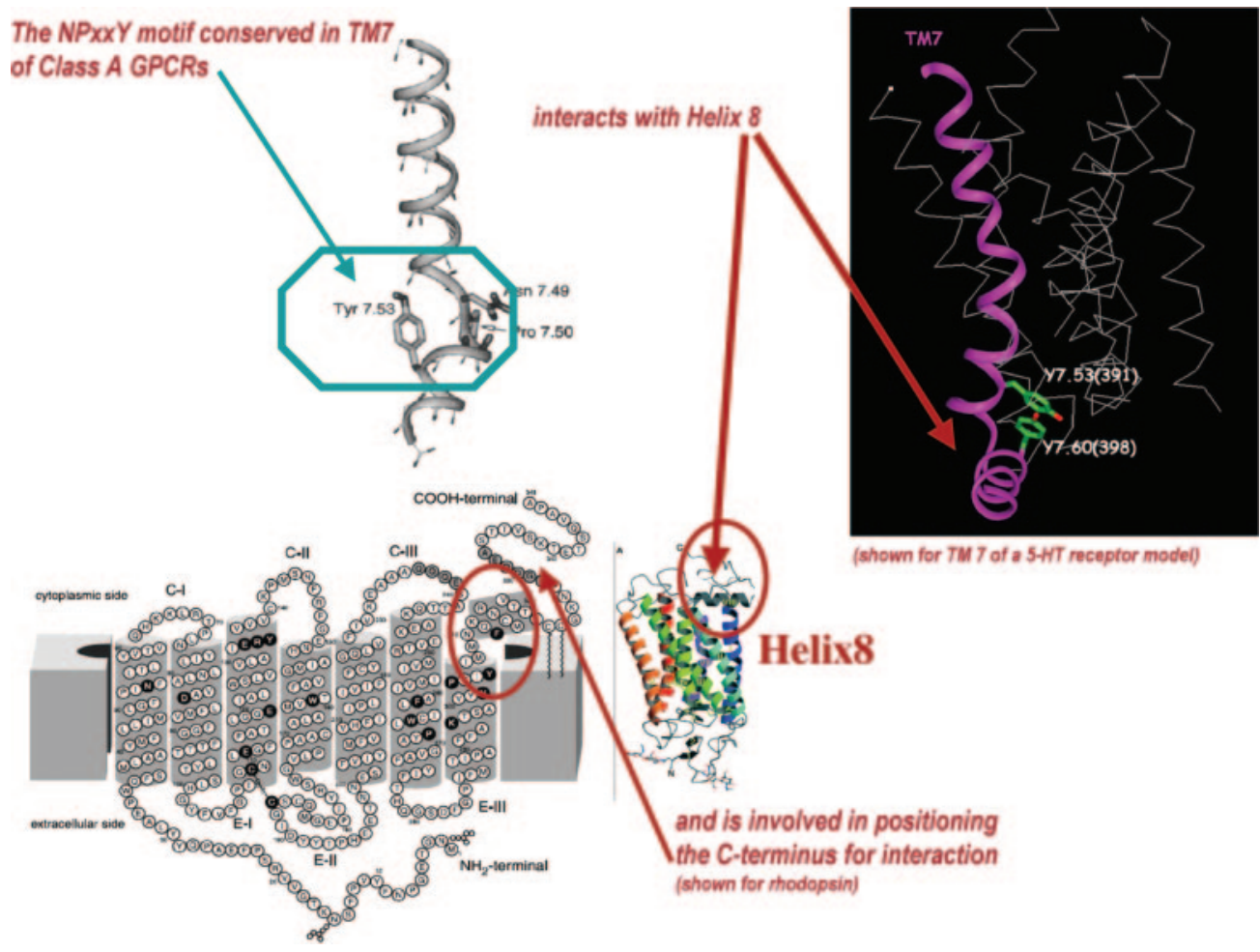

Fig. 4. The protein-protein interaction interface between a GPCR and its signaling environment is regulated by intramolecular interactions involving the NPxxY motif: The interaction between Y7.53 and the F7.60, which is in $\mathrm{Hx} 8$, controls the position of the helix and the C-terminal. This can regulate the interaction interface between the GPCRs and other proteins in the signaling cascade (e.g., PDZ domains) and may be affected differentially by the ligands, providing one mechanism for functional selectivity.

\section{The Potential Role of GPCR Oligomers in Functional Selectivity}

The specific mechanisms of ligand-specific GPCR pathway activation may also be revealed as more is understood concerning the functional consequences of receptor dimerization/ oligomerization. Many GPCRs have been observed to exist as homodimers and heterodimers or oligomers, and in some cases, this heterodimerization has been reported to lead to novel functional consequences. However, the potential structural interactions responsible for receptor oligomerization and cross-talk are largely unknown.

To understand better the functional interactions between GPCRs, it is necessary to recognize where potential receptorreceptor interfaces are located. It has been proposed that functional cross-talk between GPCRs is probably the result of conformational changes at these dimer interfaces. To investigate this hypothesis, Guo et al. (2005) have used two rhodopsin-based structural models to study the potential dimer interface of the dopamine $\mathrm{D}_{2}$ receptor. A critical aspect of this investigation involved mapping the homodimer interface in the $D_{2}$ receptor over the entire length of the fourth transmembrane segment (TM4) by the cross-linking of substituted cysteines. The susceptibility of the cysteine mutants to crosslinking is altered differentially by the presence of agonists and inverse agonists. The TM4 dimer interface in the inverse agonist-bound conformation is consistent with the dimer of the inactive form of rhodopsin modeled with constraints from atomic force microscopy (Liang et al., 2003). Cross-linking of a different set of cysteines in TM4 was slowed by inverse agonists and accelerated in the presence of agonists. Crosslinking of the latter set locks the receptor in an active state, as shown in both GTP $\gamma \mathrm{S}$ binding and cAMP accumulation assays. Thus, a conformational change at the TM4 dimer interface is part of the receptor activation mechanism (Guo et al., 2005). This is shown schematically in Fig. 5.
These results demonstrate that conformational changes in, and ultimately the rearrangement of, TM4 is critical to the activation of the $\mathrm{D}_{2}$ receptor dimer and that this aspect of the dimer interface is coupled to the structure of the binding site (Guo et al., 2005). It has been proposed that a single heterotrimeric G protein may interact with two GPCR protomers (Baneres and Parello, 2003; Filipek et al., 2004), and conformational changes at the interface may thereby mediate $G$ protein coupling and activation. Based on X-ray crystallography studies of the soluble N-terminal binding sites of metabotropic glutamate receptors, agonist binding is thought to alter the relative orientation of the dimer formed by the two extracellular binding domains (Kunishima et al., 2000; Tsuchiya et al., 2002; Kniazeff et al., 2004). Moreover, in metabotropic glutamate receptors, agonist binding has been shown to lead to a change in the distance between the cytoplasmic loops of the protomers (Tateyama et al., 2004). Such a movement must be associated with an altered relationship between the transmembrane domains of the two protomers. Although it has yet to be examined, it is proposed that known dopamine $\mathrm{D}_{2}$ functionally selective compounds (e.g., dihydrexidine, dinapsoline, and aripiprazole) might produce conformational changes that generate unique dimer interfaces that ultimately result in selective dimer-effector coupling.

\section{Impact on Research and Training}

\section{The Impact of Functional Selectivity on Quantitative Pharmacology}

The initiation of the era of "analytical pharmacology", i.e., the development and application of quantitative modeling to describe drug-receptor interactions and their consequences, can largely be attributed to the work of A. J. Clark. Along with Clark, the field has continued to develop and progress thanks in large part to the achievements of E. J. Ariens, J. H. 


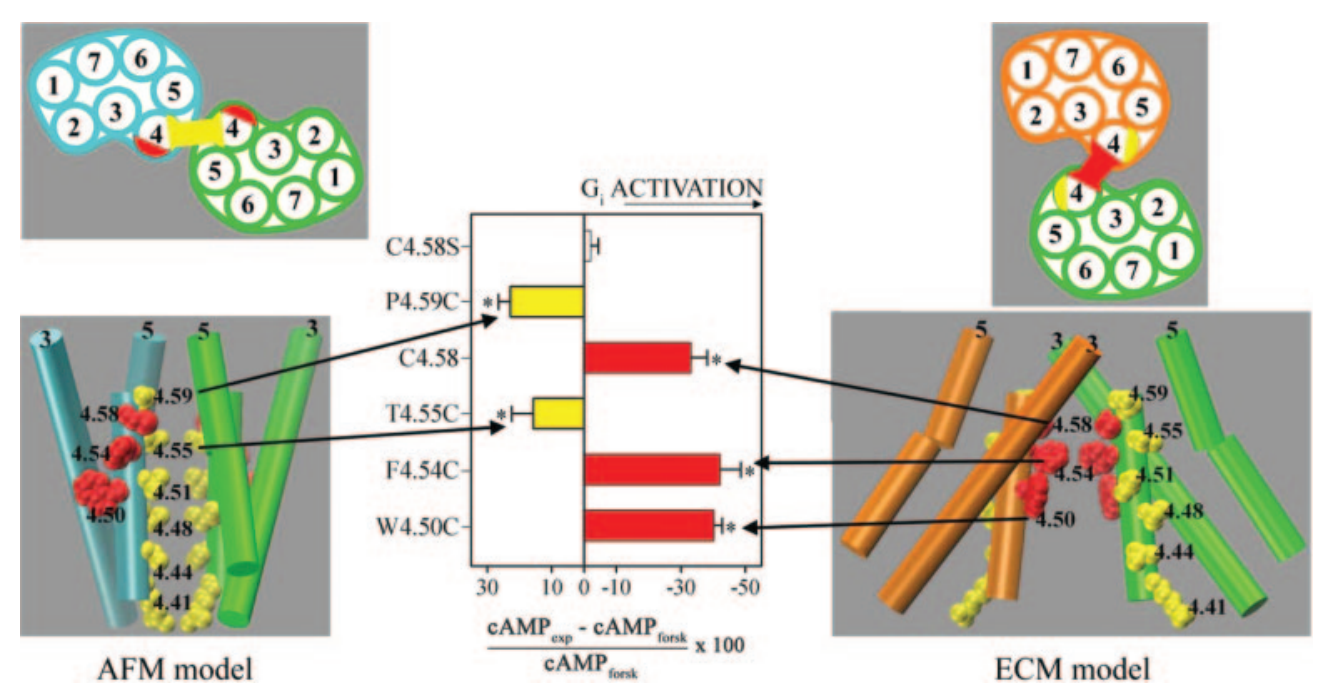

Fig. 5. Illustration of potential dimer arrangements and molecular model representations of the proposed dimer interfaces and effects of disulfide trapping of the respective interfaces on receptor activation (see Guo et al., 2005 for additional detail). Left, extracellular and side views of a symmetric TM4-TM5 interface (yellow) as proposed by Liang et al. (2003). Right, extracellular and side views of a symmetric TM4 interface (red) deduced from the squid rhodopsin two-dimensional electron density map (Davies et al., 2001). These two models are proposed to correspond to the inactive and active states, respectively. The backbone of the transmembrane segments is rendered as cylinders. Middle, the change in [cAMP] in the presence of forskolin $(100 \mu \mathrm{M})$ after treatment with copper (phenanthroline $)_{2}(100 \mu \mathrm{M})$ in cells stably expressing the appropriate cysteine mutants is shown as the mean \pm S.E.M. $(n=3-6)$. The $x$-axis is plotted so that activation of the receptor, which causes inhibition of adenylate cyclase through $\mathrm{G}_{\mathrm{i}}$, is shown to the right of the $y$-intercept. In $C 168^{4.58} \mathrm{~S}$, the maximal change of cAMP induced by dopamine was $-74 \%$. Thus, disulfide trapping of residues at the red interface activates the receptor, whereas cross-linking of residues at the yellow interface decreases spontaneous activation.

Gaddum, H. O. Schild, R. P. Stephenson, R. F. Furchgott, J. Black, T. P. Kenakin, and others. Indeed, pharmacology, by its very nature, is a quantitative discipline, and as such biological and mathematical models are indispensable as tools for designing and interpreting experiments and providing objective insights into potential mechanisms of action.

An understanding of the simple model-building process provides a foundation for subjecting experimental data to mechanistic scrutiny. There are three possibilities that must be considered if the data are not in accord with the predictions of the model. 1) The incorporation of more complex mechanisms into the model is necessary, 2) the assumptions underlying the model fail to describe accurately the process used to generate the data, or 3) the process/quality of data generation needs to be scrutinized.

According to this process, functional selectivity initially might be described by the simplest mechanism (i.e., a single state receptor model), as variations in stimulus-response coupling efficiency are sufficient to model many experimentally observed examples of tissue/cell-dependent differences in the expression of agonism for a given ligand. If one assumes for the sake of argument that 2nd and 3rd possibilities described above do not apply to the experimental approach and resulting data, the simplistic premise of a single-state receptor model becomes clearly inadequate as a mechanism that can explain phenomena such as reversals in agonist rank potencies, reversals in rank efficacies, and reversals of agonism to inverse agonism.

One direction for reconciling these experimental observations is to build more complex drug-receptor models that not only accommodate our current understanding of protein biophysics but also incorporate multiple receptor states (Christopoulos and Kenakin, 2002). The heuristic nature of these models may yield further insight into biological behavior, although the very nature of their complexity may sometimes make it difficult to test the model adequately. A potential pitfall of multi-state models is the temptation to avoid critical scrutiny of the underlying assumptions. Thus, the very model that was built to accommodate novel data might fail to describe accurately the conditions under which the data were generated. As an example, the most commonly used multistate models assume equilibrium among all reactants, an assumption that often may not be met. As shown in the cartoon in Fig. 6, steady-state or kinetic models may provide

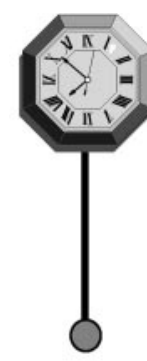

\section{Equilibrium TCM ETCM CTCM
etc.}

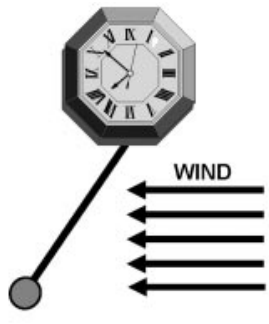

Steady-State TCAM

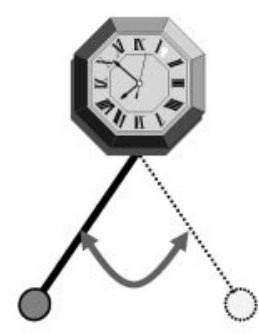

Dynamic
BIOLOGICAL RELEVANCE

Fig. 6. The three different types of models applied to biological systems are amenable to a pendulum analogy. Equilibrium models, which encompass the ternary complex model (TCM), extended TCM (ETCM), and cubic TCM (CTCM) are akin to a pendulum that is static in nature. Steady-state models, such as the ternary complex activation model (TCAM), are more realistic in that they encompass the contribution of energy (e.g., wind for the pendulum) to maintain a behavior that appears static. The most biologically relevant models, however, are dynamic models, because they reflect the fact that the system is constantly changing in time. However, the more biologically relevant, the more complex the model becomes. Adapted from Woolf and Linderman (2000). 
more realistic mechanisms for understanding biological behavior under such circumstances (Christopoulos et al., 1999; Lew et al., 2000; Woolf and Linderman, 2000). Indeed, it may be that it is timely to bring nonlinear dynamic approaches into the receptor pharmacology arena.

\section{Functional Selectivity: Do We Need to Update Pharmacological Terminology?}

In light of the pharmacological questions raised by the concept of functional selectivity, there is a need to appropriately classify GPCRs and the novel mechanisms that have been put forth to describe adequately the anomalies observed in functional pharmacology. In fact, the Nomenclature Committee of the International Union of Basic and Clinical Pharmacology (NC-IUPHAR) is developing a plan to initiate such a project. The mission of NC-IUPHAR is to 1 ) issue guidelines for receptor and ion channel classification, 2) classify the major receptor and ion channel systems, and 3) facilitate the interface between discovery of new sequences from the human genome project and designation of the derived proteins as functional receptors and ion channels.

Indeed, the publication of the human genome project marks a unique moment in scientific history in that all of the potential sequences for receptors and ion channels that have any analogy to previously known classes are now available. It is unlikely that many new ion channels or receptors have yet to be discovered, so it is the mechanistic understanding of these hypothesized ion channel and receptor sequences (as well as their biologically important polymorphisms) that is presently an important pursuit of the medical and pharmacological community. The initial difficulties lie in the fact that the primary receptor sequences must be linked to general pharmacology, as well as to the affinity and potency values of classic agonists and antagonists. However, it is clear that, for standard receptor sequences, there can be extremely diverse affinities and potencies reported in the literature (for a hands-on example of this the reader is referred to http://pdsp.cwru.edu/pdsp.asp, an interactive database of ligand-receptor affinities resulting from the National Institute of Mental Health-sponsored Psychoactive Drug Screening Program in Bryan Roth's laboratory, and to the IUPHAR website, www.iuphar-db.org).

If functional selectivity is indeed a crucial mechanism that must be considered in the drug development process, initial screens using reconstituted systems may not show the appropriate pharmacology. To select the best compounds (or indeed to understand selected lead compounds), assays dependent on several effector systems are necessary to screen for differential activation. This will provide a more accurate reflection of the characteristics of given compound, but even then, appropriate in vivo physiological models will still be required. This clearly creates a massive but necessary task for pharmacologists as was recently proposed in detail (Spedding et al., 2005). If this is the case, drug discovery may be back to drug-specific pharmacology (where each drug may have a distinct profile), rather than specific-drug pharmacology (where agents specific for a receptor have a predicted action). This is particularly the case for nuclear receptors where the local availability of coactivators and corepressors markedly modifies drug responses (NC-IUPHAR reports in preparation).

\section{Functional Selectivity and Its Impact on Drug Discovery}

There are two general questions concerning functional selectivity as it relates to industry. 1) Can functional selectivity be observed during the GPCR drug discovery process, especially within in vitro systems? 2) If observed, can functional selectivity in vitro be applied toward measures of in vivo efficacy and/or safety liabilities?

Of course, the answer to the first question is "yes". Functional selectivity is often observed with GPCRs expressed in recombinant systems, which can have an immediate impact on lead identification. However, high-throughput screening (HTS) campaigns often employ a single functional endpoint with which to characterize the activities of test compounds, an approach that can potentially lead to overlooking or triaging important compounds that signal through alternative pathways via the same receptor. For example, it has been demonstrated with both $5-\mathrm{HT}_{2 \mathrm{C}}$ and $\mathrm{D}_{2}$ ligands that relatively small structural modifications can elicit functional selectivity (more than 100-fold) without affecting receptor affinity (Miller et al., 2000; Gay et al., 2004). Therefore, it is important to collect data on ligand affinity and activity through multiple functional endpoints. However, within the realm of industry, the addition of multiple functional effectors to a HTS operation is a substantial additional cost, and it is partially for this reason that industry has been slow to move in this direction.

Even when functional selectivity can be demonstrated in vitro, it is not completely clear how it may affect in vivo efficacy and/or improved safety profiles. The $5-\mathrm{HT}_{2 \mathrm{C}}$ compounds that illustrated functionally selective profiles in vitro (i.e., high $5-\mathrm{HT}_{2 \mathrm{C}}$ receptor affinity, high GTP $\gamma \mathrm{S}$ potency, but a 100 -fold lower potency for the $5-\mathrm{HT}_{2 \mathrm{C}}$-mediated production of $\mathrm{IP}_{3}$ ) were found to produce a similar level of efficacy in both acute and chronic feeding models as those compounds considered typical potent $5-\mathrm{HT}_{2 \mathrm{C}}$ receptor agonists (Largent et al., 2002). Further in vivo examination of c-Fos activation in regions of the brain known to be involved in appetite regulation showed no difference among the compounds in the number or localization of activated neurons. Conversely, propyldihydrexidine (Fig. 3), a compound with functionally selective in vitro properties (Kilts et al., 2002), causes quite unexpected behavioral effects (Smith et al., 1997). These examples highlight the immaturity of this field and the need for additional research.

Ultimately, functional selectivity is a concept that must be considered when dealing with drug discovery. Both further discovery and a better understanding of the multiple signaling pathways coupled to various GPCRs will allow for the design of more integrated HTS assays and thus lead to more informed interpretations of ligand-receptor structure-activity relationships. Appreciating this concept also may help to explain unexpected in vivo findings of functionally weak compounds that illustrate in vivo efficacies equivalent to typical agonists.

\section{Future Directions}

A major point of discussion is how these observations of functionally selective ligands might affect traditional pharmacological principles from the bench and clinic to the classroom. For example, there is the line of thinking that the underlying mechanisms for this phenomenon should be more 
carefully illuminated before a significant push is made to establish functional selectivity as an accepted pharmacological mechanism. Proponents for this more conservative approach feel that current knowledge of local receptor milieus, the involvement of accessory and structural proteins in signaling, receptor dimerization, kinetics, and so forth is rather limited and that this uncertainty opens the door for a variety of mechanisms that might provide alternate explanation(s) without requiring major revisions in current pharmacological theory.

Although it is clear that there are many gaps in our knowledge of receptor signaling, it seems to us that functional selectivity is a real phenomenon with a plethora of supporting examples. Indeed, we are not aware of any data from appropriately controlled studies that invalidate the functional selectivity hypothesis. Furthermore, some receptor mutations have been shown to cause standard ligands to become functionally selective or to alter the signaling pattern of existing functionally selective ligands. As such, the concept must be given wider consideration by pharmacologists because of its potential relevance to both mechanistic interpretation of data, as well as its impact on ligand characterization and even drug discovery. We might consider, as an example, the dynamic nature of ligand-receptor modeling that has been continually updated as new data and new methodologies have been incorporated. Of course, the basic pharmacological tenet of "intrinsic efficacy" is particularly difficult because of the inability to reconcile it with so many examples of functional selectivity.

If one accepts that functional selectivity is a widely applicable phenomenon (regardless of whether or not it requires scrapping of traditional quantitative pharmacology), it seems clear that it will affect the way that pharmacology is taught. If the concept proves to be universal, it will have an impact directly on the training of future scientists who will affect future research and drug discovery. How this more complicated mechanism will be taught to others (e.g., medical or pharmacy students) is a challenge that will certainly need to be sorted out.

Another major point of discussion relates to the agreement on a common name for functional selectivity to avoid a pharmacological Tower of Babel. As noted in the Introduction, this phenomenon carries many monikers, some of which have different connotations to what is being described. What is evident from the data is that the examples of GPCR ligands considered to be "functionally selective" run the gamut in terms of their functional profiles. Thus, there are examples of ligands that have a broad functional profile for a specific receptor (antagonist or inverse agonist through full-agonist behaviors), whereas others demonstrate less drastic differences in their receptor-specific functional activity (e.g., fulland partial-agonist activity). Some current terms imply either specific mechanisms or a narrow range of functional possibilities (e.g., "protean agonism", "agonist-directed trafficking of stimulus", and "biased agonism"). These terms fail to accommodate situations in which there is functional "inactivity" (i.e., antagonism), and the use of the term "trafficking" is often confused with established terminology that describe receptor relocalization. Another phrase, "relative activity versus endocytosis (RAVE)", although a catchy acronym, is mechanistically restrictive.

Although the term "functional selectivity" is descriptive and mechanistically neutral (both desirable characteristics), its use to describe the concept of ligand-dependent differential regulation of receptor-coupled effector pathways is weakened by the fact that a PubMed search for "functional selectivity" results in 133 hits. Of these, only a few actually refer to the concept of ligand-dependent differential regulation of signaling via a single receptor (the concept inherent to this Perspective), whereas the majority uses the phrase in a manner that describes ligand activity as a function of receptor subtype. Thus, although "functional selectivity" may convey an appropriately neutral functional tone, its "misuse" in the literature may potentially create confusion for future publication on the issue. A term that has been suggested as a viable alternative is "ligand-induced differential signaling". It also is mechanism-neutral, would not be confused with other aspects of cellular signaling and regulation, and evokes a catchy acronym. The importance of an appropriate mechanistic classification of functional selectivity has been echoed by members of the Nomenclature Committee of IUPHAR. In fact, the NC-IUPHAR urges those who are interested to actively participate in the ongoing dialog on the issue of terminology by submitting their opinions directly (http:// www.iuphar.org/nciuphar.html). It is important to note that, although this Perspective has taken a GPCR-centric view of the receptor world, we are keenly aware that similar phenomena (e.g., selective estrogen receptor modulation) have been recognized with other receptor superfamilies (e.g., see Gronemeyer et al., 2004 for recent review). Thus, the impact of this issue spans the breadth of pharmacology

In closing, there is a need for even greater understanding of local receptor environments and the factors that might play a role in the types of anomalous observations reviewed here. These range from accessory proteins (both catalytic and organizational), receptor dimerization (both homodimers and heterodimers), alternative receptor splicing, mRNA editing, receptor polymorphisms (single nucleotide polymorphisms), trafficking of receptors, and so on. There is also a need to understand how subtle changes in ligand structure can sometimes have profound effects on functional properties. Not only will such data provide a firm mechanistic base for functional selectivity (by whatever name it is called), this knowledge also will help us to understand many apparent pharmacological anomalies and potentially lead to novel drug discovery. Some years ago, it was written that functional selectivity ". . . could yield important therapeutic advances, although it introduces a new level of complexity that will require significantly greater understanding of receptor dynamics and the interaction with transduction mechanisms" (Mailman et al., 1997, 1998). The discussions resulting from the paradoxical data found in the literature suggest that the time is ripe to explore these issues further.

\section{Acknowledgments}

This review was spurred by two symposia at the 2005 Annual Meeting of the Society for Experimental Biology (San Diego, CA) sponsored by the Division of Neuropharmacology of the American Society of Pharmacology and Experimental Therapeutics. We thank Drs. David Sibley, Charles Murrin, and Katherine Cunningham for providing the impetus to have this interesting topic aired in a thorough and organized manner. We also thank Dr. Gabriel Vargas for sharing unpublished data with the V2 vasopressin receptor and Dr. Wen Guo for creating Fig. 5. 


\section{References}

Alvarez VA, Arttamangkul S, Dang V, Salem A, Whistler JL, von Zastrow M, Grandy DK, and Williams JT (2002) mu-Opioid receptors: ligand-dependent activation of potassium conductance, desensitization, and internalization. J Neurosci 22:57695776

Anji A, Kumari M, Sullivan Hanley NR, Bryan GL, and Hensler JG (2000) Regulation of 5-HT(2A) receptor mRNA levels and binding sites in rat frontal cortex by the agonist DOI and the antagonist mianserin. Neuropharmacology 39:19962005.

Ariens EJ (1954) Affinity and intrinsic activity in the theory of competitive inhibition. I. Problems and theory. Arch Int Pharmacodyn Ther 99:32-49.

Baneres JL and Parello J (2003) Structure-based analysis of GPCR function: evidence for a novel pentameric assembly between the dimeric leukotriene B4 receptor BLT1 and the G-protein. J Mol Biol 329:815-829.

Barak LS, Oakley RH, Laporte SA, and Caron MG (2001) Constitutive arrestinmediated desensitization of a human vasopressin receptor mutant associated with nephrogenic diabetes insipidus. Proc Natl Acad Sci USA 98:93-98.

Baranski TJ, Herzmark P, Lichtarge O, Gerber BO, Trueheart J, Meng EC, Iiri T, Sheikh SP, and Bourne HR (1999) C5a receptor activation. Genetic identification of critical residues in four transmembrane helices. J Biol Chem 274:15757-15765.

Benovic JL, Staniszewski C, Mayor F Jr, Caron MG, and Lefkowitz RJ (1988) beta-Adrenergic receptor kinase. Activity of partial agonists for stimulation of adenylate cyclase correlates with ability to promote receptor phosphorylation. $J$ Biol Chem 263:3893-3897.

Berg KA, Cropper JD, Niswender CM, Sanders-Bush E, Emeson RB, and Clarke WP (2001) RNA-editing of the 5-HT(2C) receptor alters agonist-receptor-effector coupling specificity. Br J Pharmacol 134:386-392.

Berg KA, Maayani S, Goldfarb J, and Clarke WP (1998a) Pleiotropic behavior of 5-HT2A and 5-HT2C receptor agonists. Ann NY Acad Sci 861:104-110.

Berg KA, Maayani S, Goldfarb J, Scaramellini C, Leff P, and Clarke WP (1998b) Effector pathway-dependent relative efficacy at serotonin type $2 \mathrm{~A}$ and $2 \mathrm{C}$ receptors: evidence for agonist-directed trafficking of receptor stimulus. Mol Pharmacol 54:94-104

Berry SA, Shah MC, Khan N, and Roth BL (1996) Rapid agonist-induced internalization of the 5-hydroxytryptamine2A receptor occurs via the endosome pathway in vitro. Mol Pharmacol 50:306-313.

Bhatnagar A, Willins DL, Gray JA, Woods J, Benovic JL, and Roth BL (2001) The dynamin-dependent, arrestin-independent internalization of 5-hydroxytryptamine $2 \mathrm{~A}\left(5-\mathrm{HT}_{2 \mathrm{~A}}\right)$ serotonin receptors reveals differential sorting of arrestins and $5-\mathrm{HT}_{2 \mathrm{~A}}$ receptors during endocytosis. J Biol Chem 276:8269-8277.

Brewster WK, Nichols DE, Riggs RM, Mottola DM, Lovenberg TW, Lewis MH, and Mailman RB (1990) trans-10,11-Dihydroxy-5,6,6a,7,8,12b-hexahydrobenzo[aphenanthridine: a highly potent selective dopamine D1 full agonist. J Med Chem 33:1756-1764.

Burris KD, Molski TF, Xu C, Ryan E, Tottori K, Kikuchi T, Yocca FD, and Molinoff PB (2002) Aripiprazole, a novel antipsychotic, is a high-affinity partial agonist at human dopamine D2 receptors. J Pharmacol Exp Ther 302:381-389.

Campagne F, Neves S, Chang CW, Skrabanek L, Ram PT, Iyengar R, and Weinstein $\mathrm{H}$ (2004) Quantitative information management for the biochemical computation of cellular networks. Sci STKE 2004:111.

Charifson PS, Bowen JP, Wyrick SD, Hoffman AJ, Cory M, McPhail AT, and Mailman RB (1989) Conformational analysis and molecular modeling of 1-phenyl4-phenyl-, and 1-benzyl-1,2,3,4-tetrahydroisoquinolines as $\mathrm{D}_{1}$ dopamine receptor ligands. J Med Chem 32:2050-2058.

Christopoulos A and Kenakin T (2002) G protein-coupled receptor allosterism and complexing. Pharmacol Rev 54:323-374.

Christopoulos A, Parsons AM, Lew MJ, and El Fakahany EE (1999) The assessment of antagonist potency under conditions of transient response kinetics. Eur J Pharmacol 382:217-227.

Clarke WP and Bond RA (1998) The elusive nature of intrinsic efficacy. Trends Pharmacol Sci 19:270-276.

Cosi C, Carilla-Durand E, Assie MB, Ormiere AM, Maraval M, Leduc N, and Newman-Tancredi A (2006) Partial agonist properties of the antipsychotics SSR181507, aripiprazole and bifeprunox at dopamine D2 receptors: G protein activation and prolactin release. Eur J Pharmacol 535:135-144.

Cussac D, Newman-Tancredi A, Duqueyroix D, Pasteau V, and Millan MJ (2002) Differential activation of $\mathrm{G}_{\mathrm{q}} / 11$ and $\mathrm{G}_{\mathrm{i}}(3)$ proteins at 5-hydroxytryptamine $(2 \mathrm{C})$ receptors revealed by antibody capture assays: influence of receptor reserve and relationship to agonist-directed trafficking. Mol Pharmacol 62:578-589.

Davies A, Gowen BE, Krebs AM, Schertler GF, and Saibil HR (2001) Threedimensional structure of an invertebrate rhodopsin and basis for ordered alignment in the photoreceptor membrane. J Mol Biol 314:455-463.

De Deurwaerdere P, Navailles S, Berg KA, Clarke WP, and Spampinato U (2004) Constitutive activity of the serotonin $2 \mathrm{C}$ receptor inhibits in vivo dopamine release in the rat striatum and nucleus accumbens. J Neurosci 24:3235-3241.

Ebersole BJ, Visiers I, Weinstein H, and Sealfon SC (2003) Molecular basis of partial agonism: Orientation of indoleamine ligands in the binding pocket of the human serotonin 5- $\mathrm{HT}_{2 \mathrm{~A}}$ receptor determines relative efficacy. Mol Pharmacol 63:36-43.

Elphick GF, Querbes W, Jordan JA, Gee GV, Eash S, Manley K, Dugan A, Stanifer M, Bhatnagar A, Kroeze WK, et al. (2004) The human polyomavirus, JCV, uses serotonin receptors to infect cells. Science (Wash DC) 306:1380-1383.

Engelhardt B and Briskin MJ (2005) Therapeutic targeting of alpha 4-integrins in chronic inflammatory diseases: tipping the scales of risk towards benefit? Eur $J$ Immunol 35:2268-2273

Felder CC, Kanterman RY, Ma AL, and Axelrod J (1990) Serotonin stimulates phospholipase A2 and the release of arachidonic acid in hippocampal neurons by a type 2 serotonin receptor that is independent of inositol phospholipid hydrolysis. Proc Natl Acad Sci USA 87:2187-2191.

Feldman BJ, Rosenthal SM, Vargas GA, Fenwick RG, Huang EA, Matsuda-Abedini
M, Lustig RH, Mathias RS, Portale AA, Miller WL, et al. (2005) Nephrogenic yndrome of inappropriate antidiuresis. N Engl J Med 352:1884-1890.

ilipek S, Krzysko KA, Fotiadis D, Liang Y, Saperstein DA, Engel A, and Palczewski $\mathrm{K}$ (2004) A concept for $\mathrm{G}$ protein activation by $\mathrm{G}$ protein-coupled receptor dimers: the transducin/rhodopsin interface. Photochem Photobiol Sci 3:628-638.

Filizola M and Weinstein H (2005) The structure and dynamics of GPCR oligomers: a new focus in models of cell-signaling mechanisms and drug design. Curr Opin Drug Discov Devel 8:577-584.

Furchgott RF (1966) The use of -haloalkylamines in the differentiation of receptors and in the determination of dissociation constants of receptor-agonist complexes, in Adv Drug Res (Harper NJ and Simmonds AB eds) Vol. 3, pp 21-55, Academic Press, New York

Gay EA, Urban JD, Nichols DE, Oxford GS, and Mailman RB (2004) Functional selectivity of $\mathrm{D} 2$ receptor ligands in a Chinese hamster ovary hD2L cell line: evidence for induction of ligand-specific receptor states. Mol Pharmacol 66:97-105. Gether U, Lin S, Ghanouni P, Ballesteros JA, Weinstein H, and Kobilka BK (1997) Agonists induce conformational changes in transmembrane domains III and VI of the beta2 adrenoceptor. EMBO (Eur Mol Biol Organ) J 16:6737-6747.

Ghanouni P, Gryczynski Z, Steenhuis JJ, Lee TW, Farrens DL, Lakowicz JR, and Kobilka BK (2001) Functionally different agonists induce distinct conformations in the $\mathrm{G}$ protein coupling domain of the $\beta 2$ adrenergic receptor. $J$ Biol Chem $\mathbf{2 7 6}$ $24433-24436$

Gonzalez-Maeso J, Yuen T, Ebersole BJ, Wurmbach E, Lira A, Zhou M, Weisstaub N, Hen R, Gingrich JA, and Sealfon SC (2003) Transcriptome fingerprints distinguish hallucinogenic and nonhallucinogenic 5-hydroxytryptamine $2 \mathrm{~A}$ receptor agonist effects in mouse somatosensory cortex. $J$ Neurosci 23:8836-8843.

Gray JA and Roth BL (2001) Paradoxical trafficking and regulation of 5-HT(2A) receptors by agonists and antagonists. Brain Res Bull 56:441-451.

Gronemeyer H, Gustafsson JA, and Laudet V (2004) Principles for modulation of the nuclear receptor superfamily. Nat Rev Drug Discov 3:950-964.

Guo W, Shi L, Filizola M, Weinstein H, and Javitch JA (2005) Crosstalk in G protein-coupled receptors: changes at the transmembrane homodimer interface determine activation. Proc Natl Acad Sci USA 102:17495-17500.

Hanley NR and Hensler JG (2002) Mechanisms of ligand-induced desensitization of the 5-hydroxytryptamine(2A) receptor. J Pharmacol Exp Ther 300:468-477.

Hausdorff WP, Campbell PT, Ostrowski J, Yu SS, Caron MG, and Lefkowitz RJ (1991) A small region of the beta-adrenergic receptor is selectively involved in its rapid regulation. Proc Natl Acad Sci USA 88:2979-2983.

He L, Fong J, von ZM, and Whistler JL (2002) Regulation of opioid receptor trafficking and morphine tolerance by receptor oligomerization. Cell 108:271-282.

Hess EJ, Norman AB, and Creese I (1988) Chronic treatment with dopamine receptor antagonists: behavioral and pharmacologic effects on D1 and D2 dopamine receptors. J Neurosci 8:2361-2370.

Hoyer D, Clarke DE, Fozard JR, Hartig PR, Martin GR, Mylecharane EJ, Saxena PR, and Humphrey PP (1994) International Union of Pharmacology classification of receptors for 5-hydroxytryptamine (serotonin). Pharmacol Rev 46:157-203.

Jim KF, Macia RA, and Matthews WD (1985) An evaluation of the ability of a series of full alpha-1 adrenoceptor agonists to release internal calcium in venous smooth muscle. J Pharmacol Exp Ther 235:377-381.

Keith DE, Anton B, Murray SR, Zaki PA, Chu PC, Lissin DV, Monteillet-Agius G, Stewart PL, Evans CJ, and von Zastrow M (1998) mu-Opioid receptor internalization: opiate drugs have differential effects on a conserved endocytic mechanism in vitro and in the mammalian brain. Mol Pharmacol 53:377-384.

Keith DE, Murray SR, Zaki PA, Chu PC, Lissin DV, Kang L, Evans CJ, and von ZM (1996) Morphine activates opioid receptors without causing their rapid internalization. J Biol Chem 271:19021-19024.

Kenakin T (1995) Pharmacological proteus? Trends Pharmacol Sci 16:256-258.

Kenakin T (1997) Pharmacologic Analysis of Drug-Receptor Interaction. LippincottRaven, Philadelphia.

Kenakin T (2005) New concepts in drug discovery: collateral efficacy and permissive antagonism. Nat Rev Drug Discov 4:919-927.

Kikuchi T, Tottori K, Uwahodo Y, Hirose T, Miwa T, Oshiro Y, and Morita S (1995) 7-(4-[4-(2,3-Dichlorophenyl)-1-piperazinyl] butyloxy)-3,4-dihydro-2( $1 H$ )-quinolinone (OPC-14597), a new putative antipsychotic drug with both presynaptic dopamine autoreceptor agonistic activity and postsynaptic D2 receptor antagonistic activity. J Pharmacol Exp Ther 274:329-336.

Kilts JD, Connery HS, Arrington EG, Lewis MM, Lawler CP, Oxford GS, O’Malley KL, Todd RD, Blake BL, Nichols DE, et al. (2002) Functional selectivity of dopamine receptor agonists. II. Actions of dihydrexidine in D2L receptor-transfected MN9D cells and pituitary lactotrophs. J Pharmacol Exp Ther 301:1179-1189.

Kniazeff J, Bessis AS, Maurel D, Ansanay H, Prezeau L, and Pin JP (2004) Closed state of both binding domains of homodimeric $\mathrm{mGlu}$ receptors is required for full activity. Nat Struct Mol Biol 11:706-713.

Kobilka BK and Gether U (2002) Use of fluorescence spectroscopy to study conformational changes in the beta 2-adrenoceptor. Methods Enzymol 343:170-182

Kunishima N, Shimada Y, Tsuji Y, Sato T, Yamamoto M, Kumasaka T, Nakanishi S, Jingami H, and Morikawa K (2000) Structural basis of glutamate recognition by a dimeric metabotropic glutamate receptor. Nature (Lond) 407:971-977.

Kurrasch-Orbaugh DM, Parrish JC, Watts VJ, and Nichols DE (2003a) A complex signaling cascade links the serotonin2A receptor to phospholipase A2 activation: the involvement of MAP kinases. $J$ Neurochem 86:980-991.

Kurrasch-Orbaugh DM, Watts VJ, Barker EL, and Nichols DE (2003b) Serotonin 5-hydroxytryptamine(2A) receptor-coupled phospholipase $\mathrm{C}$ and phospholipase $\mathrm{A}_{2}$ signaling pathways have different receptor reserves. J Pharmacol Exp Ther 304 $229-237$.

Largent BL, Robichaud AJ, and Miller KJ (2002) Promise and progress of central G protein-coupled receptor modulators for obesity treatment. Ann Rep Med Chem 37:1-10.

Lawler CP, Prioleau C, Lewis MM, Mak C, Jiang D, Schetz JA, Gonzalez AM, Sibley DR, and Mailman RB (1999) Interactions of the novel antipsychotic aripiprazole 
(OPC-14597) with dopamine and serotonin receptor subtypes. Neuropsychopharmacology 20:612-627.

Lawler CP, Watts VJ, Booth RG, Southerland SB, and Mailman RB (1994) Discrete functional selectivity of drugs: OPC-14597. a selective antagonist for post-synaptic dopamine D2 receptors. Soc Neurosci Abstr, Abstracts 20, 525. Society for Neuroscience, Washington, DC.

Lew MJ, Ziogas J, and Christopoulos A (2000) Dynamic mechanisms of non-classical antagonism by competitive AT(1) receptor antagonists. Trends Pharmacol Sci 21:376-381.

Liang Y, Fotiadis D, Filipek S, Saperstein DA, Palczewski K, and Engel A (2003) Organization of the G protein-coupled receptors rhodopsin and opsin in native membranes. J Biol Chem 278:21655-21662.

Lieberman JA (2004) Dopamine partial agonists: a new class of antipsychotic. CNS Drugs 18:251-267.

Lovenberg TW, Brewster WK, Mottola DM, Lee RC, Riggs RM, Nichols DE, Lewis $\mathrm{MH}$, and Mailman RB (1989) Dihydrexidine, a novel selective high potency full dopamine D-1 receptor agonist. Eur J Pharmacol 166:111-113.

Mailman RB, Nichols DE, Lewis MM, Blake BL, and Lawler CP (1998) Functional effects of novel dopamine ligands: dihydrexidine and Parkinson's disease as a first step, in Dopamine Receptor Subtypes: From Basic Science to Clinical Application (Jenner P and Demirdemar R eds) pp 64-83, IOS Stockton Press, Washington, DC.

Mailman RB, Nichols DE, and Tropsha A (1997) Molecular drug design and dopamine receptors, in The Dopamine Receptors (Neve KA and Neve RL eds) pp 105-133, Humana Press, Totowa, NJ.

Miller KJ, Robichaud AJ, and Largent BL (2000) 5-HT2C receptor-mediated activation of $\mathrm{IP}_{3}$ and cGMP in HEK293 cells: evidence for agonist directed trafficking. Soc Neurosci Abstr, Abstract 26, Number 46.6. Society for Neuroscience, Washington, DC.

Mottola DM, Brewster WK, Cook LL, Nichols DE, and Mailman RB (1992) Dihydrexidine, a novel full efficacy $\mathrm{D}_{1}$ dopamine receptor agonist. $J$ Pharmacol Exp Ther 262:383-393.

Mottola DM, Kilts JD, Lewis MM, Connery HS, Walker QD, Jones SR, Booth RG, Hyslop DK, Piercey M, Wightman RM, et al. (2002) Functional selectivity of dopamine receptor agonists. I. Selective activation of postsynaptic dopamine D2 receptors linked to adenylate cyclase. J Pharmacol Exp Ther 301:1166-1178.

Mottola DM, Laiter S, Watts VJ, Tropsha A, Wyrick SD, Nichols DE, and Mailman RB (1996) Conformational analysis of D1 dopamine receptor agonists: pharmacophore assessment and receptor mapping. J Med Chem 39:285-296.

Newton RA and Elliott JM (1997) Mianserin-induced down-regulation of human 5-hydroxytryptamine2A and 5-hydroxytryptamine2C receptors stably expressed in the human neuroblastoma cell line SH-SY5Y. J.Neurochem 69:1031-1038.

O'Connor KA and Roth BL (2005) Finding new tricks for old drugs: an efficient route for public-sector drug discovery. Nat Rev Drug Discov 4:1005-1014.

Parrish JC, Braden MR, Gundy E, and Nichols DE (2005) Differential phospholipase $\mathrm{C}$ activation by phenylalkylamine serotonin 5-HT $2 \mathrm{~A}$ receptor agonists. $J$ Neurochem 95:1575-1584.

Parrish JC and Nichols DE (2006) Serotonin 5- $\mathrm{HT}_{2 \mathrm{~A}}$ receptor activation leads to phospholipase C-dependent release of 2-arachidonoylglycerol (2-AG). J Neurochem 99:1164-1175

Peroutka SJ and Snyder SH (1980) Regulation of serotonin2 (5-HT2) receptors labeled with $\left[{ }^{3} \mathrm{H}\right]$ spiroperidol by chronic treatment with the antidepressant amitriptyline. J Pharmacol Exp Ther 215:582-587.

Portoghese PS (1965) A new concept on the mode of interaction of narcotic analgesics with receptors. J Med Chem 8:609-616.

Prioleau C, Visiers I, Ebersole BJ, Weinstein H, and Sealfon SC (2002) Conserved helix 7 tyrosine acts as a multistate conformational switch in the $5 \mathrm{HT} 2 \mathrm{C}$ receptor. Identification of a novel "locked-on" phenotype and double revertant mutations. J Biol Chem 277:36577-36584.

Qandil AM, Lewis MM, Jassen A, Leonard SK, Mailman RB, and Nichols DE (2003) Synthesis and pharmacological evaluation of substituted naphth $[1,2,3$ de]isoquinolines (dinapsoline analogues) as $\mathrm{D}_{1}$ and $\mathrm{D}_{2}$ dopamine receptor ligands. Bioorg Med Chem 11:1451-1464.

Rabin RA, Regina M, Doat M, and Winter JC (2002) 5-HT2A receptor-stimulated phosphoinositide hydrolysis in the stimulus effects of hallucinogens. Pharmacol Biochem Behav 72:29-37.

Ransohoff RM (2005) Natalizumab and PML. Nat Neurosci 8:1275.

Roettger BF, Ghanekar D, Rao R, Toledo C, Yingling J, Pinon D, and Miller LJ (1997) Antagonist-stimulated internalization of the $\mathrm{G}$ protein-coupled cholecystokinin receptor. Mol Pharmacol 51:357-362.

Rosenthal W, Antaramian A, Gilbert S, and Birnbaumer M (1993) Nephrogenic diabetes insipidus. A V2 vasopressin receptor unable to stimulate adenylyl cyclase. $J$ Biol Chem 268:13030-13033.

Roth BL and Chuang DM (1987) Multiple mechanisms of serotonergic signal transduction. Life Sci 41:1051-1064.

Roth BL and Ciaranello RD (1991) Chronic mianserin treatment decreases 5-HT2 receptor binding without altering 5-HT2 receptor mRNA levels. Eur J Pharmacol 207:169-172

Roth BL, Sheffler DJ, and Kroeze WK (2004) Magic shotguns versus magic bullets: selectively non-selective drugs for mood disorders and schizophrenia. Nat Rev Drug Discov 3:353-359.

Ryman-Rasmussen JP, Nichols DE, and Mailman RB (2005) Differential activation of adenylate cyclase and receptor internalization by novel dopamine D1 receptor agonists. Mol Pharmacol 68:1039-1048.

Schulz R, Wuster M, and Herz A (1979) Supersensitivity to opioids following the chronic blockade of endorphin action by naloxone. Naunyn-Schmiedeberg's Arch Pharmacol 306:93-96.

Shapiro DA, Renock S, Arrington E, Sibley DR, Chiodo LA, Roth BL, and Mailman RB (2003) Aripiprazole, a novel atypical antipsychotic drug with a unique and robust pharmacology. Neuropsychopharmacology 28:1400-1411. mith HP, Nichols DE, Mailman RB, and Lawler CP (1997) Locomotor inhibition, yawning and vacuous chewing induced by a novel dopamine D2 post-synaptic receptor agonist. Eur J Pharmacol 323:27-36.

Sneddon WB, Syme CA, Bisello A, Magyar CE, Rochdi MD, Parent JL, Weinman EJ, bou-Samra AB, and Friedman PA (2003) Activation-independent parathyroid hormone receptor internalization is regulated by NHERF1 (EBP50). J Biol Chem 278:43787-43796.

Spedding M, Jay T, Costa e Silva J, and Perret L (2005) A pathophysiological paradigm for the therapy of psychiatric disease. Nat Rev Drug Discov 4:467-476.

Stahl SM (2001a) Dopamine system stabilizers, aripiprazole, and the next generation of antipsychotics, part 1, "Goldilocks" actions at dopamine receptors. J Clin Psychiatry 62:841-842.

Stahl SM (2001b) Dopamine system stabilizers, aripiprazole, and the next generation of antipsychotics, part 2: illustrating their mechanism of action. $J$ Clin Psychiatry 62:923-924.

Sternini C, Spann M, Anton B, Keith DE Jr, Bunnett NW, von Zastrow M, Evans C and Brecha NC (1996) Agonist-selective endocytosis of mu opioid receptor by neurons in vivo. Proc Natl Acad Sci USA 93:9241-9246.

Stout BD, Clarke WP, and Berg KA (2002) Rapid desensitization of the serotonin(2C) receptor system: effector pathway and agonist dependence. J Pharmacol Exp Ther 302:957-962.

Swaminath G, Deupi X, Lee TW, Zhu W, Thian FS, Kobilka TS, and Kobilka B (2005) Probing the beta2 adrenoceptor binding site with catechol reveals differences in binding and activation by agonists and partial agonists. J Biol Chem 280:2216522171.

Swaminath G, Xiang Y, Lee TW, Steenhuis J, Parnot C, and Kobilka BK (2004) Sequential binding of agonists to the beta2 adrenoceptor. Kinetic evidence for intermediate conformational states. J Biol Chem 279:686-691.

Tamminga CA and Carlsson A (2002) Partial dopamine agonists and dopaminergic stabilizers, in the treatment of psychosis. Curr Drug Targets CNS Neurol Disord 1:141-147.

Tateyama M, Abe H, Nakata H, Saito O, and Kubo Y (2004) Ligand-induced rearrangement of the dimeric metabotropic glutamate receptor 1alpha. Nat Struct Mol Biol 11:637-642.

Tran TM, Friedman J, Qunaibi E, Baameur F, Moore RH, and Clark RB (2004) Characterization of agonist stimulation of cAMP-dependent protein kinase and G protein-coupled receptor kinase phosphorylation of the beta2-adrenergic receptor using phosphoserine-specific antibodies. Mol Pharmacol 65:196-206.

Trester-Zedlitz M, Burlingame A, Kobilka B, and von ZM (2005) Mass spectrometric analysis of agonist effects on posttranslational modifications of the beta-2 adrenoceptor in mammalian cells. Biochemistry 44:6133-6143.

Tsuchiya D, Kunishima N, Kamiya N, Jingami H, and Morikawa K (2002) Structural views of the ligand-binding cores of a metabotropic glutamate receptor complexed with an antagonist and both glutamate and Gd3+. Proc Natl Acad Sci USA 99:2660-2665.

Urban JD, Vargas GA, von Zastrow M, and Mailman RB (2006) Aripiprazole has functionally selective actions at dopamine $\mathrm{D}_{2}$ receptor-mediated signaling pathways. Neuropsychopharmacology, in press.

Van AG, Van RM, Sciot R, Dubois B, Vermeire S, Noman M, Verbeeck J, Geboes K, Robberecht W, and Rutgeerts P (2005) Progressive multifocal leukoencephalopathy after natalizumab therapy for Crohn's disease. N Engl J Med 353:362-368.

Visiers I, Ballesteros JA, and Weinstein H (2002) Three-dimensional representations of G protein-coupled receptor structures and mechanisms. Methods Enzymol 343: $329-371$.

Visiers I, Hassan SA, and Weinstein H (2001) Differences in conformational properties of the second intracellular loop (IL2) in 5HT(2C) receptors modified by RNA editing can account for G protein coupling efficiency. Protein Eng 14:409-414.

Weinstein H (2006) Hallucinogen actions on 5-HT receptors reveal distinct mechanisms of activation and signaling by G protein-coupled receptors. AAPS J 7:E871E884.

Whistler JL, Chuang HH, Chu P, Jan LY, and von Zastrow M (1999) Functional dissociation of mu opioid receptor signaling and endocytosis: implications for the biology of opiate tolerance and addiction. Neuron 23:737-746.

Whistler JL, Gerber BO, Meng EC, Baranski TJ, von ZM, and Bourne HR (2002) Constitutive activation and endocytosis of the complement factor 5a receptor: evidence for multiple activated conformations of a $\mathrm{G}$ protein-coupled receptor. Traffic 3:866-877.

Whistler JL and von Zastrow M (1998) Morphine-activated opioid receptors elude desensitization by beta-arrestin. Proc Natl Acad Sci USA 95:9914-9919.

Willins DL, Berry SA, Alsayegh L, Backstrom JR, Sanders-Bush E, Friedman L, and Roth BL (1999) Clozapine and other 5-hydroxytryptamine-2A receptor antagonists alter the subcellular distribution of 5-hydroxytryptamine-2A receptors in vitro and in vivo. Neuroscience 91:599-606.

Woolf PJ and Linderman JJ (2000) From the static to the dynamic: three models of signal transduction in G-protein coupled receptors, in Biomedical Applications of Computer Modeling (Christopoulos A ed), pp 87-108, CRC Press, Inc., Boca Raton, FL.

Yu Y, Zhang L, Yin X, Sun H, Uhl GR, and Wang JB (1997) Mu opioid receptor phosphorylation, desensitization, and ligand efficacy. J Biol Chem 272:2886928874.

Zhang J, Ferguson SS, Barak LS, Bodduluri SR, Laporte SA, Law PY, and Caron MG (1998) Role for G protein-coupled receptor kinase in agonist-specific regulation of mu-opioid receptor responsiveness. Proc Natl Acad Sci USA 95:7157-7162.

Address correspondence to: Dr. Richard B. Mailman, CB 7160, 7011 NC Neurosciences Hospital, University of North Carolina School of Medicine, Chapel Hill, NC 27599-7160. E-mail: richard_mailman@med.unc.edu 